\title{
SIBLING CANNIBALISM IN JUVENILE BARRAMUNDI, LATES CALCARIFER (ACTINOPTERYGII: PERCIFORMES: CENTROPOMIDAE), REARED UNDER DIFFERENT LIGHT CONDITIONS
}

\author{
Antonysiluvai JESU AROCKIARAJ ${ }^{{ }^{*}}$ and Samuel APPELBAUM ${ }^{2}$ \\ ${ }^{1}$ Department of Marine Biotechnology, Marine Molecular Genetics Lab, Cheju National University, \\ 66 Jejudaehakno, Ara-Dong, Jeju 690 756, Republic of Korea \\ ${ }^{2}$ The Bengis Centre for Desert Aquaculture, The Albert Katz Department of Dryland Biotechnologies, The Jacob \\ Blaustein Institute for Desert Research, Ben-Gurion University of the Negev, Sde Boker Campus 84990, Israel
}

Jesu Arockiaraj A., Appelbaum S. 2011. Sibling cannibalism in juvenile barramundi, Lates calcarifer (Actinopterygii: Perciformes: Centropomidae), reared under different light conditions. Acta Ichthyol. Piscat. 41 (1): 7-11.

Background. Cannibalism occurs at various ages or sizes depending on fish species and the respective environments. Barramundi, Lates calcarifer (Bloch, 1790), is a popular and valuable species in aquaculture on the Asian and Australian continents. In its culture, cannibalism can cause severe losses during the early stages of development particularly before fish reach a length of about $10 \mathrm{~cm}$. Hence the present study aimed to study the effect of the two photoperiods, constant darkness and continuous light on the rate of sibling cannibalism in barramundi juveniles reared indoors under intensive conditions.

Materials and methods. The indoor experimental setup consisted of two separate systems labelled system 1 and 2. Each system consisted of three rectangular rearing tanks each of $60 \mathrm{~L}$ capacity connected to a mechanical and a biological water-cleaning unit. System 1 was kept under $24 \mathrm{~h}$ of light provided by two 36 watt fluorescent tubes. System 2 was kept under $24 \mathrm{~h}$ of darkness except for a short period of 6 min during each feeding time. Each rearing tank was randomly stocked with 187 juveniles. A commercial fish feed was provided to the fish by hand $a d$ libitum four times during the day time. The experiment was conducted for 112 days.

Results. In both light and dark systems, larger specimens were much more active during feeding, chasing smaller siblings away from the provided feed, leaving them only the remains to feed on. The accumulated observed mortality was similar under both dark and light conditions. In the present study although feed was provided $a d$ libitum, cannibalism still occurred under both light and dark conditions. However, the rate of cannibalism was significantly $(P<0.05)$ lower under dark conditions. The results show that a potential predator can swallow a prey up to a maximum of $67 \%$ of its own body length. Similar growth performances were observed in the fish groups reared under dark and light conditions.

Conclusion. The application of constant darkness is therefore a useful strategy in significantly reducing cannibalism when rearing barramundi. Furthermore, such a strategy also leads to the formation of a more uniform population of fish which is a desire of the grower.

Keywords: barramundi, cannibalism, photoperiod, light condition

\section{INTRODUCTION}

Cannibalism is a common behaviour in teleost species (Kestemont et al. 2003), that has been observed so far in 36 of 410 fish families and occurs at various ages or sizes depending on fish species and the respective environments (Hecht and Pienaar 1993). Among the commonly cultured fish species, cannibalism has been reported in walleye, Stizostedion vitreum (see Cuff 1980); north African catfish, Clarias gariepinus (see Hecht and Appelbaum 1988, Almazán-Rueda et al. 2004); common carp, Cyprinus car- pio (see van Damme et al. 1989); Atlantic cod, Gadus morhua (see Folkvord 1991, 1997); European perch, Perca fluviatilis (see Baras et al. 2003); sampa, Heterobranchus longifilis (see Baras et al. 1998, 1999, Kerdchuen and Legendre 1991); dorada, Brycon moorei (see Baras et al. 2000); green swordtail, Xiphophorus hellerii (see Jones et al. 1998); orange-spotted grouper, Epinephelus coioides (see Hseu et al. 2003); giant grouper, Epinephelus lanceolatus (see Hseu et al. 2004); barramundi, Lates calcarifer (see Qin et al. 2004); and in many other fish species.

\footnotetext{
* Correspondence: Dr. A. Jesu Arockiaraj, Departmet of Marine Biotechnology, Marine Molecular Genetics Lab, Cheju National University, 66 Jejudaehakno, Ara-Dong, Jeju 690 756, Republic of Korea, phone: 0082-62-754 3472, fax: 0082-62-754 3493, e-mail: jesuaraj@yahoo.com.
} 
The barramundi, known also as 'barramunda' or 'giant sea perch' is a popular and valuable species in aquaculture on the Asian and Australian continents (Tucker et al. 2002). In barramundi culture, cannibalism can cause severe losses during the early stages of development particularly before fish reach a length of about $10 \mathrm{~cm}$ (Qin et al. 2004). In barramundi hatcheries frequent size grading of the fingerlings has to be employed to reduce the rate of cannibalism. This practice however is not only labour intensive but also stresses the entire fish stock being graded. Although size heterogeneity strongly affects cannibalism, the intensity of cannibalism also varies according to environmental conditions (Hecht and Pienaar 1993). Previous studies on cannibalism in fish have focused mainly on regularly grading fish by size (Hokanson and Lien 1986), reducing stocking density (Smith and Reay 1991) and feeding to full satiation (Qin and Fast 1996), while little research has been directed to manipulation of abiotic factors (Hecht and Pienaar 1993).

Dou et al. (2000) reported that light intensity significantly affects cannibalistic behaviour in bastard halibut, Paralichthys olivaceus. Qin et al. (2004) reported that low light intensity and provision of refuges significantly reduced cannibalism in barramundi, yet the exact effect of $24 \mathrm{~h}$ constant darkness or $24 \mathrm{~h}$ continuous light on cannibalism has not been studied.

The present study aims to study the effect of the two photoperiods, constant darkness (24-h D) and continuous light (24-h Lt) on the rate of sibling cannibalism in barramundi juveniles reared indoors under intensive conditions.

\section{MATERIALS AND METHODS}

Experimental system. The indoor experimental setup consisted of two separate systems labelled system 1 and 2 . Each system consisted of three rectangular rearing tanks each of $60 \mathrm{~L}$ capacity connected to a mechanical and a biological water cleaning unit made of a $100 \mathrm{~L}$ water-cleaning tank filled with volcanic gravel and strongly aerated water. System 1 was kept under $24 \mathrm{~h}$ of light (24-h Lt) provided by two 36 watt fluorescent tubes. System 2 was kept under $24 \mathrm{~h}$ of darkness (24-h D) except for a short period of 6 min during each feeding time. The two systems were filled with dechlorinated freshwater which was recirculated and pumped to each rearing tank at the rate of $3 \mathrm{~L} \cdot \mathrm{min}^{-1}$. Twenty percent of the water volume in each system was replaced daily to compensate for losses due to evaporation and sludge removal from the water cleaning unit. An air blower provided compressed air for maintaining oxygen levels in the rearing tanks above $4 \mathrm{mg} \mathrm{O}_{2} \cdot \mathrm{L}^{-1}$. Ammonia and nitrite levels in the rearing water were below $(<0.04$ $\mathrm{ppm})$ the toxicity levels for barramundi. Water temperature in the systems was kept at $28 \pm 1^{\circ} \mathrm{C}$ using thermostatically controlled electric heaters. In the course of the study, the experimental fish were transferred (after 70 rearing days) to larger rearing tanks of $100 \mathrm{~L}$ each.

Experimental fish. Juvenile barramundi produced via induced spawning (Maagan Michael Hatchery, Israel), with an average weight $=0.73 \mathrm{~g}$ (64 days post hatching) were used for the 112 day experiment. Each rearing tank was randomly stocked with 187 juveniles. This study has been carried out in accordance with the country's regulations on experiments on animals.

Feed and feeding. A commercial fish feed $(3 \mathrm{~mm}$ sinking pellets: protein $46 \%$, lipid $12 \%$, fibre $4.6 \%$, and ash $8 \%$; 'Shivuk Rannan', Israel) was provided to the fish by hand ad libitum four times during the day time.

Observation. Representative fish samples $(n=30)$ from each experimental group were weighed every two weeks to monitor growth performance. Survival [\%], weight gain $[\mathrm{g}]$, specific growth rate (SGR) $\left[\% \cdot \mathrm{d}^{-1}\right]$, feed conversion ratio (FCR) and protein efficiency ratio (PER) were calculated as follows: survival [\%] = (no. of fish stocked - no. of mortalities $) \times 100 /$ no. of fish stocked; weight gain $[\mathrm{g}]=$ average final weight $[\mathrm{g}]$ - average initial weight $[\mathrm{g}]$; specific growth rate $\left[\% \cdot \mathrm{d}^{-1}\right]=100$ $\times(\ln$ average final weight $-\ln$ average initial weight $) /$ trial [days]; feed conversion ratio $=$ feed consumption $[\mathrm{g}] /$ weight gain $[\mathrm{g}]$ and protein efficiency ratio = weight gain $[\mathrm{g}]$ / protein intake.

Observed mortality. Observed mortality was recorded daily. Observed dead fish, not caused by cannibalism, were counted and recorded as mortality which was calculated as follows: Mortality [\%] $=100 \times$ (number of dead fish / initial number of fish).

Cannibalism. All live individuals in each rearing tank were counted once every two weeks and the rate of cannibalism was calculated as follows: Cannibalism [\%] $=100$ $\times$ (number of missing fish - number of observed dead fish/ initial number of fish).

Predator-prey size ratio. Predators, from both light and dark conditions when found grasping their prey, were netted out and the length and weight of both the predator and its prey were measured and the ratio calculated using the following formula described by Hahm and Langton (1984); $\operatorname{SCORE}_{j}=\ln \left(W_{i} / W_{j}\right)$; where $W_{j}=$ predator weight and $W_{i}=$ prey weight.

Statistics. The growth and survival data were analyzed using one-way ANOVA and Tukey's Multiple Range Test (Zar 1984). At the termination of the experiment the weights of all surviving fish in each treatment were recorded and plotted to produce the Gaussian Population Distribution Curve using Statistica ${ }^{\circledR}$ software version 7.

\section{RESULTS}

Feeding behaviour. In both light and dark conditions, larger specimens were much more active during feeding, chasing smaller siblings away from the provided feed, leaving them only the remains to feed on. During feeding, fish under light condition exhibited a uniform schooling towards the feed, while in the dark condition they were scattered and approached the feed individually.

Observed mortality. The accumulated observed mortality (not caused by cannibalism) was similar under 24-h D (4.6\%) and 24-h Lt (4.1\%) conditions.

Observed cannibalism. In both light and dark condi- 
tions, larger specimens made repeated attempts to catch smaller siblings. When an attempt to seize a prey was successful, the predator would catch and swallow the prey head first. However, occasionally, due to the prey size, the predator was unable either to continue to swallow its prey or to release it, the prey remaining stuck in the predator's mouth causing the death of both.

In the present study although feed was provided ad libitum, cannibalism still occurred under both light and dark conditions. However, the rate of cannibalism was significantly $(P<0.05)$ lower under dark conditions $(20.31 \%)$ and higher $(27.5 \%)$ in light condition.

Predator-prey size ratio. The results show that a potential predator can swallow a prey up to a maximum of $67 \%$ of its own body weight (as occurred under light condition on day 61 of the experiment).

Growth and survival. The growth performances are presented in Table 1. Similar growth performances were observed in the fish groups reared under dark and light conditions. Significantly $(P<0.05)$ however, highest survival was observed in the groups reared under constant darkness compared with the groups reared under continuous light.

Gaussian population distribution curve. Statistical analyses of Gaussian Population Distribution confirmed that fish reared under dark condition were more uniform in size and showed a normal population distribution curve (Fig. 1). On the contrary, fish reared under light conditions showed higher heterogeneity in size and an abnormal distribution (size distribution deviates from normality) of population (Fig. 2).

\section{DISCUSSION}

Previous studies have shown that food availability affects cannibalism in fish (Hokanson and Lien 1986, Qin and Fast 1996). Parazo et al. (1991) reported that although

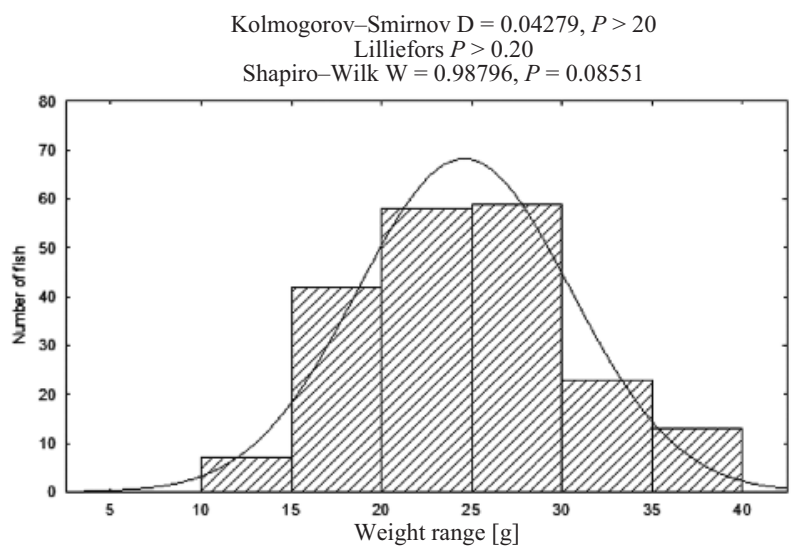

Fig. 1. Normal population distribution curve of juvenile barramundi, Lates calcarifer, reared under constant darkness

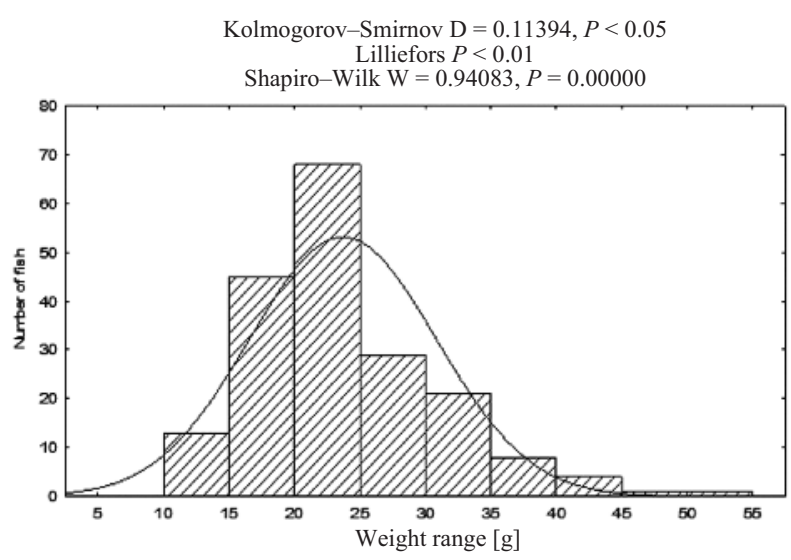

Fig. 2. Size distribution deviates from normality curve of barramundi, Lates calcarifer, reared under continuous light conditions

Growth performances of juvenile barramundi, Lates calcarifer, reared under different light conditions

\begin{tabular}{lcc}
\hline Parameter & 24 h light (24-h Lt) & 24 h dark $(24-\mathrm{h}$ D) \\
\hline Initial weight [g] & $0.73 \pm 0.32$ & $0.73 \pm 0.32$ \\
Weight after 2 weeks [g] & $1.86^{\mathrm{a}} \pm 0.41$ & $1.59^{\mathrm{a}} \pm 0.37$ \\
Weight after 4 weeks [g] & $2.52^{\mathrm{a}} \pm 0.23$ & $2.37^{\mathrm{a}} \pm 0.35$ \\
Weight after 6 weeks [g] & $5.88^{\mathrm{a}} \pm 0.49$ & $6.08^{\mathrm{a}} \pm 0.49$ \\
Weight after 8 weeks [g] & $9.27^{\mathrm{a}} \pm 1.13$ & $9.80^{\mathrm{a}} \pm 2.07$ \\
Weight after 10 weeks [g] & $12.06^{\mathrm{a}} \pm 0.92$ & $12.23^{\mathrm{a}} \pm 0.59$ \\
Weight after 12 weeks [g] & $16.11^{\mathrm{a}} \pm 0.46$ & $16.42^{\mathrm{a}} \pm 0.57$ \\
Weight after 14 weeks [g] & $17.69^{\mathrm{a}} \pm 0.90$ & $17.76^{\mathrm{a}} \pm 0.92$ \\
Final weight [g] & $19.84^{\mathrm{a}} \pm 2.6$ & $20.09^{\mathrm{a}} \pm 1.2$ \\
Weight gain [g] & $19.11^{\mathrm{a}} \pm 3.1$ & $19.36^{\mathrm{a}} \pm 2.3$ \\
Weight gain [\%] & $2617.9^{\mathrm{a}} \pm 192.3$ & $2652.1^{\mathrm{a}} \pm 103.2$ \\
FCR & $1.67^{\mathrm{a}} \pm 0.61$ & $1.65^{\mathrm{a}} \pm 0.29$ \\
PER & $2.07^{\mathrm{a}} \pm 0.41$ & $2.1^{\mathrm{a}} \pm 0.38$ \\
SGR [\% $\mathrm{d}^{-1}$ ] & $2.38^{\mathrm{a}} \pm 0.73$ & $2.39^{\mathrm{a}} \pm 0.42$ \\
Survival [\%] & $68.44^{\mathrm{a}} \pm 7.6$ & $75.04^{\mathrm{b}} \pm 3.2$ \\
\hline
\end{tabular}

${ }^{\mathrm{a}}$ and ${ }^{\mathrm{b}}$ denote significant differences at $P<0.05$ level by one-way ANOVA and Tukey's Multiple Test. 
the extent of cannibalism in barramundi is size-dependent, the ability of a cannibal to detect conspecifics depends on the habitat complexity and ambient light levels. For visual-feeder fish, searching, chasing, and capturing prey require some degree of light. Hecht and Appelbaum (1988) and Hecht and Pienaar (1993) reported that dim light significantly reduced the incidence of territorial aggressive behaviour and cannibalism in African catfish.

In the present study although feed was provided ad libitum cannibalism still occurred in both treatments, thus cannibalism in juvenile barramundi is ongoing, in spite of ad libitum feeding. The rate of cannibalism, however, was significantly $(P<0.05)$ lower under dark condition, possibly due to reduction in fish activity. The rate of the recorded accumulated mortality, not caused by cannibalism, was similar under 24-h Lt and 24-h D conditions, However survival rate was significantly lower in the 24-h Lt system, indicating a crucial contribution of cannibalism to the overall survival rate of the population. The present study shows that cannibalism in barramundi can be reduced when constant darkness is provided. In contrast, under light condition aggressive behaviour was more pronounced and this in turn was reflected in a significantly $(P<0.5)$ higher rate of cannibalism.

Although the present findings show that dark condition significantly reduces the rate of cannibalism in barramundi juveniles, studies of other species reported different results on the effect of light levels on cannibalism. Cannibalism in dorada, Blycon moorei, occurred during the daytime and at night and even persisted in permanent darkness (Baras et al. 2000). Dou et al. (2000) reported that cannibalism among juvenile bastard halibut was more frequent in light than in dark condition. Appelbaum and Kamler (2000) and Hecht and Pienaar (1993) reported that north African catfish increase browsing and swimming activity and reduce levels of cannibalism and territorial aggression in dark condition resulting in better growth performance. Again the present results show clearly that dark condition reduced cannibalism and increased survival in juvenile barramundi significantly.

The results of predator-prey size ratio agrees with an early studies by Parazo et al. (1991) and Qin et al. (2004) who found that a barramundi can swallow a sibling with a body length of $70 \%$ or less of its own. The present results suggest that sibling cannibalism in juvenile barramundi can begin when body length of a cannibal reaches the body length of about one and half that of the prey fish. From the results of the present findings a $4.5 \mathrm{~cm}$ long barramundi can swallow a sibling prey of $3 \mathrm{~cm}$ long. Finally although fish in the present study were weaned from live Artemia to take dry feed, cannibalism still prevailed under ad libitum feeding on dry feed.

\section{CONCLUSION}

The rate of sibling cannibalism in juvenile barramundi can be significantly reduced by providing dark condition, without affecting other growth parameters. The application of constant darkness is therefore a useful strategy in significantly reducing cannibalism when rearing barramundi. Furthermore, such a strategy also leads to the formation of a more uniform population of fish which is a desire of the grower. Finally this strategy may be useful in rearing other cannibalistic species.

\section{ACKNOWLEDGEMENTS}

The Bengis Centre for Desert Aquaculture, Albert Katz International School for Desert Studies, Blaustein Center for Scientific Cooperation, Ben-Gurion University of the Negev, Israel is gratefully acknowledged for providing the postdoctoral fellowship grant to the first author A. Jesu Arockiaraj during 2007-2009. Mr. David Benzion and Mr. Alan Wass are thanked for their technical help and Mr. Shomen Mukherjee for assisting in the statistical analyses.

\section{REFERENCES}

Appelbaum S., Kamler E. 2000. Survival, growth, metabolism and behaviour of Clarias gariepinus (Burchell 1822) early stages under different light conditions. Aquacultural Engineering 22 (4): 269-287. DOI: 10.1016/S0144-8609(00)00054-6.

Almazán-Rueda P., Schrama J.W., Verreth J.A.J. 2004. Behavioural responses under different feeding methods and light regimes of the African catfish (Clarias gariepinus) juveniles. Aquaculture 231 (1-4): 347-359. DOI: $10.1016 / j$.aquaculture.2003.11.016.

Baras E., Kestemont P., Mélard C. 2003. Effect of stocking density on the dynamics of cannibalism in sibling larvae of Perca fluviatilis under controlled conditions. Aquaculture 219 (1-4): 241-255. DOI: 10.1016/S0044-8486(02)00349-6.

Baras E., Maxi M.Y.J., Ndao M., Mélard C. 2000. Sibling cannibalism in dorada under experimental conditions. II. Effect of initial size heterogeneity, diet and light regime on early cannibalism. Journal of Fish Biology 57 (4): 1021-1036. DOI: 10.1111/j.1095-8649.2000.tb02208.x.

Baras E., Tissier F., Philippart J.-C., Mélard C. 1999. Sibling cannibalism among juvenile vundu under controlled conditions. II. Effect of body weight and environmental variables on the periodicity and intensity of type II cannibalism. Journal of Fish Biology 54 (1): 106-118. DOI: 10.1111/j.1095-8649.1999.tb00615.x.

Baras E., Tissier F., Westerloppe L., Mélard C., Philippart J.C. 1998. Feeding in darkness alleviates density-dependent growth of juvenile vundu catfish Heterobranchus longifilis (Claridae). Aquatic Living Resources 11 (5): 335-340. DOI: 10.1016/S0990-7440(98)80004-1.

Cuff W.R. 1980. Behavioral aspects of cannibalism in larval walleye Stizostedion vitreum. Canadian Journal of Zoology 58 (8): 1504-1507. DOI: 10.1139/z80-207.

Dou S., Seikai T., Tsukamoto K. 2000. Cannibalism in Japanese flounder juveniles, Paralichthys olivaceus, reared under controlled conditions. Aquaculture 182 (1-2): 149-159. DOI: 10.1016/S0044-8486(99)00256-2.

Folkvord A. 1991. Growth, survival and cannibalism of cod juveniles (Gadus morha): effects of feed type, starvation and fish size. Aquaculture 97 (1): 41-59.

DOI: 10.1016/0044-8486(91)90278-F. 
Folkvord A. 1997. Ontogeny of cannibalism in larval and juvenile fishes with special emphasis on Atlantic cod. Pp. 251-278. In: Chambers R.C., Trippel E.A. (eds.) Early life history and recruitment in fish populations. Chapman and Hall, London.

Hahm W., Langton R. 1984. Prey selection based on predator/prey weight ratios for some northwest Atlantic fish. Marine Ecology - Progress Series 19 (1-2): 1-5.

Hecht T., Appelbaum S. 1988. Observations on intraspecific aggression and coeval sibling cannibalism by larval and juvenile Clarius guriepinars (Clariidae: Pisces) under controlled conditions. Journal of Zoology 214 (1): 21-44. DOI: 10.1111/j.1469-7998.1988.tb04984.x.

Hecht T., Pienaar A.G. 1993. A review of cannibalism and its implications in fish larviculture. Journal of the World Aquaculture Society 24 (2): 246-261. DOI: $10.1111 / j .1749-7345.1993 . t b 00014 . x$.

Hokanson K.E.F., Lien G.J. 1986. Effects of diets growth and survival of larval walleyes. Progressive Fish-Culturist 48: 250-258. DOI: 10.1577/1548-8640(1986)48<250:EODOGA >2.0.CO;2.

Hseu J.-R., Chang H.-F., Ting Y.-Y. 2003. Morphometric prediction of cannibalism in larviculture of orange-spotted grouper, Epinephelus coioides. Aquaculture 218 (1-4): 203-207. DOI: 10.1016/S0044-8486(02)00315-0.

Hseu J.-R., Hwang P.-P., Ting Y.-Y. 2004. Morphometric model and laboratory analysis of intracohort cannibalism in giant grouper Epinephelus lanceolatus fry. Fisheries Science 70 (3): 482-486. DOI: 10.1111/j.1444-2906.2004.00829.x.

Jones C.L.W., Kaiser H., Webb G.A., Hecht T. 1998. Filial cannibalism in the swordtail Xiphophorus helleri (Poeciliidae). Aquarium Sciences and Conservation 2 (2): 79-88. DOI: 10.1023/A:1009620300967.

Kerdchuen N., Legendre M. 1991. Influence de la fréquence et de la période de nourrissage sur la croissance et l'efficacité alimentraire d'un silure african, Heterobranchus longifilis (Telestei, Claridae). Aquatic Living Resources 4 (4): 241-248. DOI: 10.1051/alr:1991025.
Kestemont P., Jourdan S., Houbart M., Mélard C., Paspatis M., Fontaine P., Cuvier A., Kentouri M., Baras E. 2003. Size heterogeneity, cannibalism and competition in cultured predatory fish larvae: biotic and abiotic influences. Aquaculture 227 (1-4): 333-356. DOI: 10.1016/S0044-8486(03)00513-1.

Parazo M.M., Avila E.M., Reyes D.M.jr. 1991. Size-and weight-dependent cannibalism in hatchery-bred sea bass (Lates calcarifer Bloch). Journal of Applied Ichthyology 7 (1): 1-7. DOI: 10.1111/j.1439-0426.1991.tb00588.x.

Qin J., Fast A.W. 1996. Size and feed dependent cannibalism with juvenile snakehead Channa striatus. Aquaculture 144 (4): 313-320. DOI: 10.1016/0044-8486(96)01299-9.

Qin J.G., Mittiga L., Ottolenghi F. 2004. Cannibalism reduction in juvenile barramundi Lates calcarifer by providing refuges and low light. Journal of the World Aquaculture Society 35 (1): 113-118. DOI: 10.1111/j.1749-7345.2004.tb01067.x.

Smith C., Reay P. 1991. Cannibalism in teleost fishes. Reviews in Fish Biology and Fisheries 1 (1): 41-64. DOI: 10.1007/BF00042661.

Tucker J.W., Russell D.J., Rimmer M.A. 2002. Barramundi culture: a success story for aquaculture in Asia and Australia. World Aquaculture Magazine 33 (3): 53-59.

van Damme P.V., Appelbaum S., Hecht T. 1989. Sibling cannibalism in koi carp, Cyprinus carpio L., larvae and juveniles reared under controlled conditions. Journal of Fish Biology 34 (6): 855-863. DOI: 10.1111/j.1095-8649.1989.tb03369.x.

Zar J.H. 1984. Biostatistical analysis. II edn. Prentice-Hall International Incorporation, Englewood Cliffs, NJ, USA.

Received: 14 December 2009

Accepted: 6 July 2010

Published electronically: 25 March 2011 